\title{
The Water pH Levels in Breeding Places Associated with The Presence of Larva Aedes Aegypti in Endemic and Non-Endemic Areas of Dengue Hemorrhagic Fever (DHF)
}

\author{
Nurul Hidayah ${ }^{1}$, Dwi Rahmawati ${ }^{2}$ \\ \{hiragi_12@yahoo.com ${ }^{1}$,dwislamet21@gmail.com $\left.{ }^{2}\right\}$ \\ Health Promotion Department Sari Mulia University, Banjarmasin, Indonesia ${ }^{1,2}$
}

\begin{abstract}
One of the efforts to reduce the incidence of Dengue Hemorrhagic Fever (DHF) is to control the breeding of Aedes aegypti mosquito vectors. The suitable water quality of breeding place can affect the vector breeding. The $\mathrm{pH}$ level is one of the chemical parameters contained in the water of breeding place. This research was conducted using the quantitative analytical method with the case-control approach. The case group was the breeding place in endemic areas and the control group in nonendemic areas. The sample size of each group was 41 containers. The data obtained were analyzed using the Spearman correlation test to find out the correlation of $\mathrm{pH}$ level with the larva and Mann-Whitney test to analyze the difference in $\mathrm{pH}$ level in endemic and non-endemic areas. It found that most $\mathrm{pH}$ levels in endemic areas were normal or at intervals of $\mathrm{pH}$ 6-7.8 (63.4\%), whereas in non-endemic areas most had $\mathrm{pH}<6$ or $>7.8$ $(87.8 \%)$. The presence of larvae was found to be highest in endemic areas $(68.3 \%)$, whereas in non-endemic areas it was only $40 \%$. The result of the statistical analysis showed that the correlation value in the endemic region was 0.462 , and in the nonendemic area was 0.478 . The $\mathrm{p}$-value for differences in $\mathrm{pH}$ levels in endemic and nonendemic areas is 0.000 . There was a significant association between $\mathrm{pH}$ levels and larvae in endemic and non-endemic areas with moderate strength. Also, there was a significant difference between $\mathrm{pH}$ levels in endemic and non-endemic areas.
\end{abstract}

Keywords: Aedes aegypti, Dengue Hemorrhagic Fever, Larvae, pH levels

\section{Introduction}

Dengue Hemorrhagic Fever (DHF) is a dangerous disease and a serious public health problem in tropical and sub-tropical regions around the world [1]. This disease transmitted to humans through the bite of Aedes aegypti mosquitoes which infected with dengue virus. Dengue Hemorrhagic Fever often causes outbreaks and can cause death in a short time [2].

Recorded Crude Fatality Rate (CFR) of DHF patients decreased in 34 provinces, but the Incident Rate (IR) increased. In 2015, the incidence rate was 129,650 people and 1,071 of them died $(\mathrm{IR}=50.75 ; \mathrm{CFR}=0.83 \%)$. Compared to 2016 , the number of patients was 204,171 and the number of deaths was $1,598(\mathrm{IR}=78.85$; $\mathrm{CFR}=0.78 \%)$. Although in general, there has been a decline, in South Kalimantan Province, the incidence of dengue still occurs in all districts/cities in 2016 [3]. 
South Kalimantan Province has declared as the DHF outbreak status in 2015. Also, it ranked the 6th highest incidence of DHF in Indonesia ( IR = 101.05) in 2016. In 2015, from 13 districts/cities in South Kalimantan Province were obtained 4,098 cases of DHF with 28 people died. In 2016, there were 4,009 cases, with 29 people died [3].

One of the regions in South Kalimantan Province that designated as an outbreak in the last 2 years was Banjar Regency. Banjar Regency includes 17 sub-districts with 23 health centers. Among these health centers, 11 centers were identified with DHF endemic areas $(47.8 \%)$. The endemic area with the highest dengue cases is in Martapura District [4].

The data above shows that DHF is a problem that must be controlled for its spread. One of them is by breaking the transmission chain, which is controlling the vector Aedes aegypti. Premature breeding sites Aedes aegypti (larvae) are in water reservoirs [5].

Based on the results of previous studies, the characteristics of water reservoirs most favored by Aedes aegypti mosquitoes to breed are well water sources, dark in color, no lid, not exposed to direct sunlight, and not drained more than a week [6]. The survival of Aedes aegypti larvae is also inseparable from the adequacy of organic substances available in water, and this is related to the water quality of breeding sites. Water quality is an important factor that determines the existence of life in water, which is determined based on observations of various parameters, namely physics and chemistry [7]. One of the chemical water parameters that can affect the breeding of Aedes aegypti larvae is $\mathrm{pH}$.

The $\mathrm{pH}$ levels are the degree of acidity used to express acidity or basicity. The $\mathrm{pH}$ range ranges from 0 to 14. The $\mathrm{pH}$ value of less than 7 indicates an acidic environment, while the above 7 indicates an alkaline environment [8]. The results of Grahaperkasa's study (2016) found that the average number of larvae that developed into mosquitoes in water with $\mathrm{pH} 5$ was $76.5 \%$, pH 7 was $98 \%$, and $\mathrm{pH} 9$ was $86.5 \%$. This shows the possibility of a correlation between water $\mathrm{pH}$ and the proliferation of mosquito vectors. Therefore, this study conducted to determine the association of $\mathrm{pH}$ levels with larvae presence in endemic and non-endemic areas [9].

\section{Method}

This research is an observational analytic, quantitative research with a case-control design approach. Case groups are breeding places in endemic areas, and control groups are breeding places in non-endemic areas.

The population in this study is all breeding sites of Aedes aegypti in Martapura District, which are endemic areas of DHF in Banjar Regency, South Kalimantan Province. The research sample was the breeding place for Aedes aegypti in Tanjung Rema Darat Village (the village with the highest incidence of DHF in Martapura District) in July 2018.

Samples were taken by purposive sampling technique with breeding place inclusion criteria that were used as research samples: 1) Types of water reservoirs where breeding is a water reservoir for daily needs; 2) The source of water used is well water; 3) No natural predators found; 4) There is no abatesation in the last 3 months; 5) Not drained in the past 1 week.

Based on the results of the preliminary survey, there were 70 inhabitants according to the inclusion criteria. The sample size in this study is 41 breeding places based on the results of sample calculations with Slovin formula.

Collecting data on larvae is carried out by observing visually in the water reservoir. The taking of water samples is carried out with the water stage where the breeding is taken using 
dipper then put into a bottle. Samples that have been taken stored in the cooler box then taken to the BBTKLPP laboratory for $\mathrm{pH}$ measurement.

The data obtained were analyzed using the Spearman-Rho correlation test to determine the correlation of $\mathrm{pH}$ levels with the presence of Aedes aegypti larvae studied in endemic and non-endemic areas. Also, the Mann-Whitney test was used to analyze differences in $\mathrm{pH}$ levels in endemic and non-endemic areas. Then the results of the analysis are presented and concluded.

\section{Result}

\subsection{Characteristics of Aedes aegypti Mosquito Breeding Sites}

The frequency distribution of the characteristics of the Aedes aegypti mosquito breeding sites includes the color, the presence of the cover, and the location of water reservoirs in endemic areas and non-endemic DHF are presented in Table 1.

Table 1. Characteristics of Aedes aegypti Mosquito Breeding Sites

\begin{tabular}{|c|c|c|c|c|c|}
\hline \multirow{2}{*}{ No } & \multirow{2}{*}{ Characteristic } & \multicolumn{2}{|c|}{ Endemic Area } & \multicolumn{2}{|c|}{ Non-Endemic Area } \\
\hline & & f & $\%$ & $\mathbf{F}$ & $\%$ \\
\hline \multirow[t]{4}{*}{1} & Color: & & & & \\
\hline & - Dark & 29 & 70.7 & 6 & 14.6 \\
\hline & - Bright & 12 & 29.3 & 35 & 85.4 \\
\hline & Total & 41 & 100 & 41 & 100 \\
\hline \multirow[t]{4}{*}{2} & Lid existence & & & & \\
\hline & - Not Exist & 26 & 63.4 & 4 & 9.8 \\
\hline & - Exist & 15 & 36.6 & 37 & 90.2 \\
\hline & Total & 41 & 100 & 41 & 100 \\
\hline \multirow[t]{4}{*}{3} & Position & & & & \\
\hline & - Outside & 2 & 4,9 & 13 & 31.7 \\
\hline & - Inside & 39 & 95.1 & 28 & 68.3 \\
\hline & Total & 41 & 100 & 41 & 100 \\
\hline
\end{tabular}

Based on Table 1, it is known that the breeding sites of Aedes aegypti mosquitoes in endemic areas are mostly dark $(70.7 \%)$, do not have a lid $(63.4 \%)$, and are located inside the house $(95.1 \%)$. The characteristics of breeding places in non-endemic areas are mostly possessed bright colors (85.4\%), have a lid (90.2\%), and are located inside the house (68.3\%).

\subsection{Water pH Level of Aedes aegypti Mosquito Breeding Site}

The $\mathrm{pH}$ level of the water where the Aedes aegypti mosquito breeds are categorized into less than $6(<6)$ or $>7.8$ and 6-7.8. This category is based on research conducted by Ridha (2013) that the average $\mathrm{pH}$ value in a positive water reservoir containing larvae is at $\mathrm{pH}$ 6-7.8 (normal acidity category) and $<6$ or $>7.8$ (poor category)[10].

Levels of $\mathrm{pH}$ 6-7.8 are mostly found in endemic areas (63.4\%) and in non-endemic areas only about $12.2 \%$. The highest $\mathrm{pH}<6$ or $>7.8$ was found in non-endemic areas $(87.8 \%)$ than in endemic areas (36.6\%) (Figure 1). 


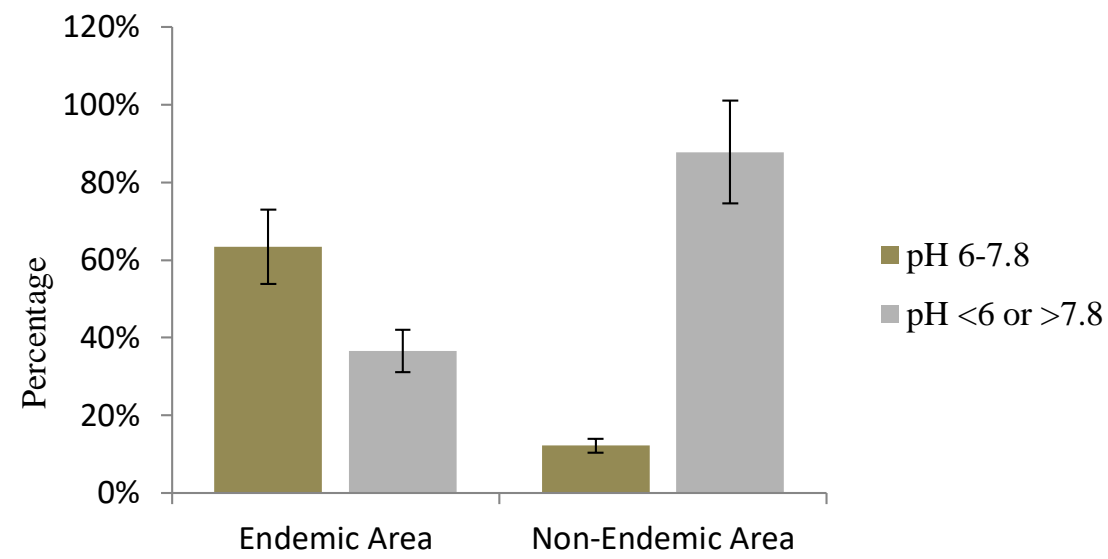

Fig 1. Comparison of $\mathrm{pH}$ levels in endemic and non-endemic areas in Banjar District, South Kalimantan Province, Indonesia

\subsection{The Presence of Aedes aegypti Mosquito Larvae}

Observation results of larvae found that from 41 water reservoirs in each region, most larvae found in endemic areas $(68.3 \%)$. The regions that are least found larvae are nonendemic areas $(85.4 \%)$ (Figure 2).

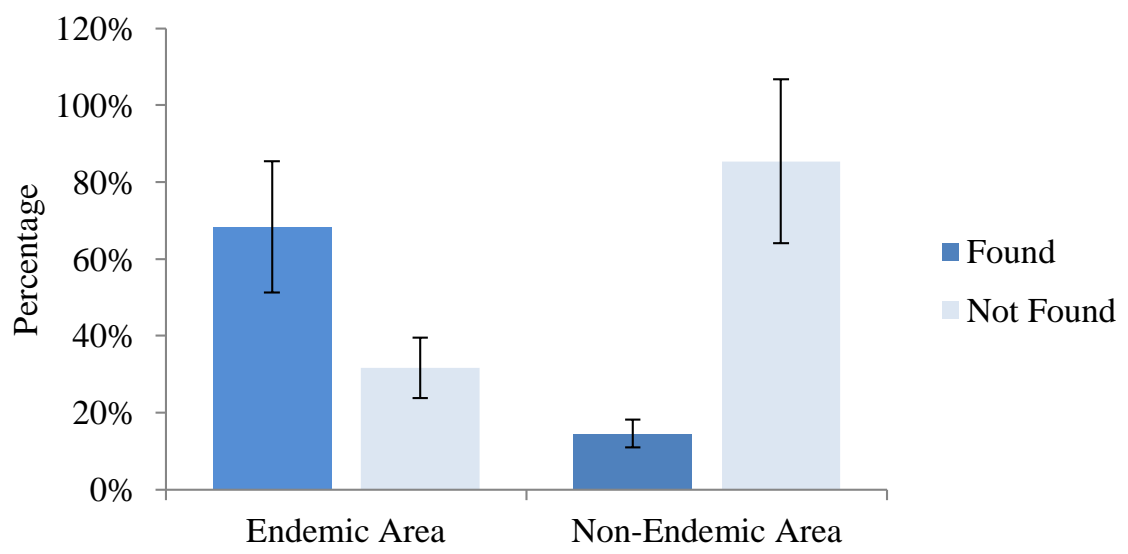

Fig 2. Comparison of larval presence in endemic and non-endemic areas in Banjar District, South Kalimantan Province, Indonesia

\subsection{Correlation of $\mathrm{pH}$ Levels with Larval Presence}

Based on the results of cross-tabulation between $\mathrm{pH}$ levels and larvae in endemic areas, it was found that most of the breeding sites with $\mathrm{pH}$ 6-7.8 were found larvae (84.6\%). Breeding 
sites with $\mathrm{pH}$ levels $<6$ or $>7.8$ were mostly not found in larvae $(60 \%)$. The results of the statistical analysis obtained p-value $=0.002$, which shows that there is a significant relationship between $\mathrm{pH}$ levels with larvae presence. The coefficient correlation is 0.462 , or the strength of the relationship is moderate, and the direction of the positive relationship is the better the $\mathrm{pH}$ level (6-7.8), the more breeding places are found larvae (Table 2).

Table 2. Correlation analysis of $\mathrm{pH}$ with larvae presence in an endemic area in Banjar District, South Kalimantan Province, Indonesia

\begin{tabular}{|c|c|c|c|c|c|}
\hline \multirow{2}{*}{$\mathrm{pH}$} & \multicolumn{2}{|c|}{ Larvae presence } & \multirow{2}{*}{$\mathrm{p}$-value } & \multirow{2}{*}{$\begin{array}{l}\text { Coefficient } \\
\text { correlation }\end{array}$} & \multirow{2}{*}{ Remark } \\
\hline & Found (\%) & Not Found (\%) & & & \\
\hline $6-7.8$ & 84.6 & 15.4 & \multirow{2}{*}{0.002} & \multirow{2}{*}{0.462} & \multirow{2}{*}{ Correlated } \\
\hline$<6$ or $>7.8$ & 40.0 & 60.0 & & & \\
\hline
\end{tabular}

In Table 3, it was found that most of the larvae found at the breeding sites had a $\mathrm{pH}$ of 6$7.8(60.0 \%)$ in non-endemic areas. Whereas for the $\mathrm{pH}$ category $<6$ or $>7.8$, most were not found larvae $(91.7 \%)$. Statistical analysis shows that there is a significant correlation between $\mathrm{pH}$ levels and larvae in non-endemic areas $(\mathrm{p}$-value $=0.000)$. The strength of the relationship is medium with a positive direction $\left(\mathrm{R}^{2}=0.478\right)$ or the better the $\mathrm{pH}$ level, the more breeding sites found.

Table 3. Correlation analysis of $\mathrm{pH}$ with larvae presence in the non-endemic area in Banjar District, South Kalimantan Province, Indonesia

\begin{tabular}{cccccc}
\hline \multirow{2}{*}{$\mathrm{pH}$} & \multicolumn{2}{c}{ Larvae presence } & p-value & $\begin{array}{c}\text { Coefficient } \\
\text { correlation }\end{array}$ & Remark \\
\cline { 2 - 3 } & Found (\%) & Not Found (\%) & & 0.478 & Correlated \\
\hline $6-7.8$ & 60.0 & 40.0 & 0.002 & & \\
$<6$ or $>7.8$ & 8.3 & 91.7 & & & 0.002 \\
\hline
\end{tabular}

\subsection{The Difference in pH Level of Water for Breeding Sites in Endemic and Non- Endemic Areas}

Statistical results also showed a significant difference between $\mathrm{pH}$ levels in endemic and nonendemic areas $(\mathrm{p}$-value $=0.000)$. The $\mathrm{pH}$ range in endemic areas is 4.63-8.28 $($ mean $=6.49)$ while in non-endemic areas is 4.19-7.44 (mean $=5.46)($ Figure 3$)$. 


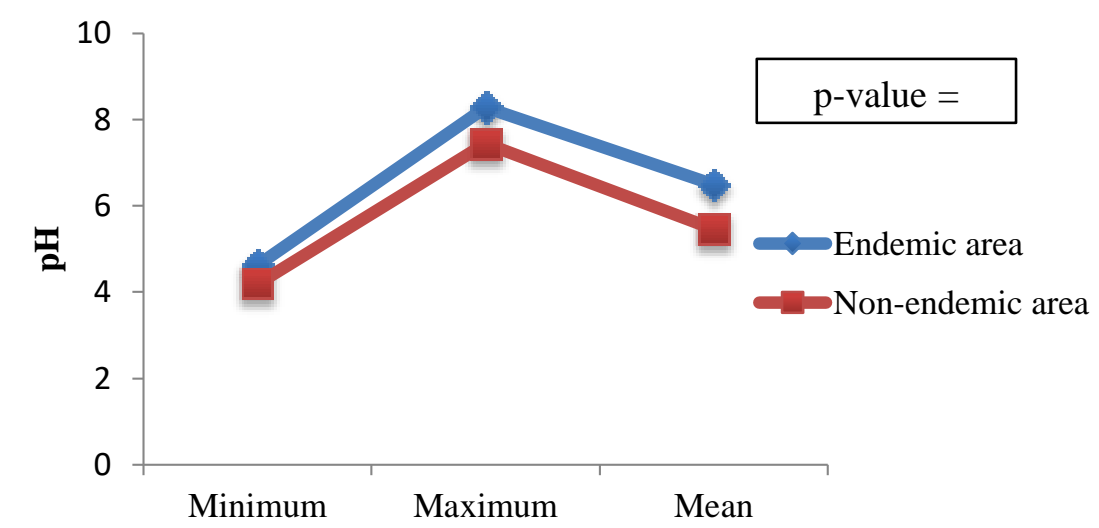

Fig 3. The difference $\mathrm{pH}$ analysis of the endemic area and non-endemic area in Banjar District, South Kalimantan Province, Indonesia

\section{Discussion}

The results showed that the breeding sites of Aedes aegypti in endemic areas were more potential to breed. Besides, $\mathrm{pH}$ levels in endemic areas are mostly in the normal category (67.8). Therefore, containers in endemic areas become more conducive places for Aedes aegypti mosquitoes to breed compared to non-endemic areas.

This research is in line with Clark and Hidayat's research in Sayono (2011), found that the $\mathrm{pH}$ of the breeding water is a factor that determines the growth of Aedes aegypti larvae. Larvae will die at $\mathrm{pH} \leq 3$ and $\geq 12$. The optimum growth of Aedes aegypti larvae is at intervals of $\mathrm{pH}$ 6-7.5. Fauziah's study (2012) also concluded that a neutral level of water acidity has the potential to become a breeding ground for Aedes aegypti mosquitoes [11].

The results also found that the $\mathrm{pH}$ level of the breeding water was significantly associated with the presence of larvae, both in endemic and non-endemic areas. This proves that a neutral $\mathrm{pH}$ level causes the Aedes aegypti mosquito to develop. This result is supported by the results of Mazda's research, et al. (2016) that $\mathrm{pH}$ levels are associated with larvae density. High larval density was at $\mathrm{pH} 6.86 \pm 0.99$, and moderate density was at $\mathrm{pH} 7.06 \pm 6.78$ [12]. This research was also supported by the research of Thangamathi et al. (2014), it was found that there was a relation between the physical-chemical characteristics of the water in which breeding and larvae density included $\mathrm{pH}$, calcium, and phosphate factors which had a positive relation. The strength of the relation is $0.2,0.99$, and 0.22 .

Olayemi's research, et al. (2010) showed a significant difference in the number of larvae at different $\mathrm{pH}$ levels of water [13]. Also, research by Umar and Donpedro in Rao, et al. (2011) found that the $\mathrm{pH}$ of water can affect the oxygen transportation and osmoregulation, so it has an impact on mosquitos [14].

The results of this research also showed a significant difference between $\mathrm{pH}$ levels in endemic and non-endemic areas, where $\mathrm{pH}$ levels in endemic areas proved to be more neutral. The $\mathrm{pH}$ parameter of water that is too acidic or too alkaline will easily result in larval death. One factor that can affect larval survival is food availability. Too acidic $\mathrm{pH}$ is thought to inhibit plankton growth while it is known that plankton is one of the biggest food sources for larvae, with reduced food sources for larval larvae to maintain their survival, is very small [15]. 
Another thing that is thought to be closely related to the state of $\mathrm{pH}$ and the presence of larvae is the formation of cytochrome oxidase enzymes in the body of the larvae that function in the metabolic process. The formation of these enzymes is strongly influenced by the high and low levels of oxygen dissolved in water. An atmosphere that is too acidic will cause rapid growth of microbes, which will also reduce oxygen levels in the water. Such conditions are thought to inhibit the formation of cytochrome oxidase enzymes in the body of larvae. This can also affect larval survival [15].

Acknowledgments. This research was supported by the Ministry of Research, Technology, and Higher Education in the scheme of beginner lecturer research grant 2018.

\section{References}

[1] WHO.:Dengue Data and statistic Regional Office for South-East Asia http://www.searo.who.int. (2015)

[2] Meilson H.E. Sallata.: Hubungan karakteristik lingkungan fisik dan kimia dengan keberadaan larva Aedes aegypti di wilayah endemis DBD Kota Makassar. Makassar: Universitas Hasanuddin.pp.27-38.(2014)

[3] Depkes RI.:Data dan Informasi Kesehatan Profil Kesehatan Indonesia 2016 Pusat Data dan Informasi Kementerian Kesehatan RI.(2016)

[4] P2PL Dinas Kesehatan Kabupaten Banjar.: Data DBD Perbulan Dinas Kabupaten Banjar Tahun 2016 Martapura: Dinkes Kabupaten Banjar.( 2016)

[5] Nadifah F.: Identifikasi Larva Nyamuk Pada Tempat Penampungan Air di Padukuhan Dero Condong Catur Kabupaten Sleman Jurnal Kesehatan Masyarakat Andalas Vol. 10.pp. 172-178.( 2016)

[6] Hidayah N, Iskandar, Abidin Z.: Prevention of Dengue Hemorrhagic Fever (DHF) Associated with the Aedes aegypti Larvae Presence based on the Type of Water Source J.Trop Life Science.Vol.7 pp.115-120.( 2017)

[7] Khoiriyah.: Perbedaan Parameter Fisika dan Kimia Air Perindukan Berdasarkan Keberadaan Jentik Aedes aegypti di Kota Semarang Semarang: Universitas Muhammadiyah Semarang.pp.926. (2010)

[8] Kasetyaningsih T and Sundari S.: Perbedaan Antara House Index yang Melibatkan Pemeriksaan Sumur pada Survei Vektor Dengue di Dusun Pepe Bantul Jurnal Kedokteran YARSI Yogyakarta .Vol.14.pp.034-037. (2007)

[9] Grahaperkasa, Vegi.:Uji Ketahanan Telur Nyamuk Aedes aegypti pada Air dengan pH 5, 7, dan 9 Repository Poltekkes Bandung.pp.4-6 (2016)

[10] Ridha MR.:The Relation of Environmental Condition and Container to the Existence of the Aedes aegypti Larvae in Dengue Haemorrhagic Fever Endemic Areas in Banjarbaru Jurnal Buski .Vol.4.pp.33-137.(2013)

[11] Fauziah, NF. Karakteristik Sumur Gali dan Keberadaan Jentik Nyamuk Aedes aegypti KESMAS. Vol 8.pp. 81-87.(2012)

[12] Madzlan F.:Breeding characteristic of Aedes mosquitoes in dengue risk area Procedia-Social and Behavioral Sciences Vol.234.pp.164-172.(2016)

[13] Olayemi IK.: Distribution of mosquito larvae in relation to physico-chemical characteristics of breeding habitats in Minna, North Central Nigeria RIF Vol 1.pp.49-53.(2010)

[14] Rao BB.: Characteristics of Aedes (Stegomyia) Albopictus Skuse (Diptera: Culicidae) breeding sites Southeast Asian J Trop Med Public Health. Vol 42.pp.1077-1082.(2011)

Sallata MHE.: Hubungan Karakteristik Lingkungan Fisik dan kimia dengan Keberadaan Larva Aedes aegypti di Wilayah Endemis DBD Kota Makassar Makassar: Universitas Hasanuddin.pp.40-57.(2014) 